\title{
Measurement of Visual Discrimination Ability among Government Elementary School Children Age 4-8
}

Sumaira Gul*

Dr. Muhammad Naeemullah**

Dr. Sajid Rehman ${ }^{* * *}$

\begin{abstract}
This study was carried out to measure the visual discrimination ability of govt. elementary school children in District Swabi, Khyber Pakhtunkhwa. The main objectives of study were: (i) to measure visual discrimination ability among elementary school children aged 4-8 years, (ii) to compare visual discrimination ability of rural and urban government elementary school children age 4-8, (iii) to compare visual discrimination ability of male and female Government elementary school children age 4-8 years. For this purpose null hypothesis were developed, (i) there was no significant difference in visual discrimination of age group 4-8 years, (ii) there was no significant difference in rural and urban government school children age 4-8 years, (iii) there was no significant difference in male and female government school children age 4-8 years. Three hundred and twenty students of government elementary schools were taken as sample of the study. An empirical research design was used to conduct the study. For collection of data, worksheets were developed and data were analyzed statistically through SPSS by applying mean, percentage, median, and t-test to get the results of the study. It was observed that visual discrimination ability increased with age, it was highest at age group 7-8 years. The research will be beneficial for elementary school children, teachers, curriculum planners, and future researchers.
\end{abstract}

Keywords: Visual discrimination, male/female School children, Rural/urban Govt. schools, Elementary education

\section{Introduction}

Visual discrimination includes distinguishing objectives from surrounding stimuli. According to Gibson (1969), the technique by means of which an infant learns to make a difference in objects and symbols is through visual discrimination ability. Young students must be able to grasp the differences in similarities and differences of objects in addition to of alphabets so that children may develop their reading abilities as per their age and grade. Children who face difficulty in visual discrimination of identifying the accurate orientation of numbers and letters often show poor performance as compared to their associates at educational level, have lower reading capabilities, and have poor handwriting than their friends (Venter, et al, 2018). Individuals require certain level of visible discrimination ability for successful operation of the ADL. The concept of ADL is activities for daily living. (Teufel \& Nanay, 2017). The medium to facilitate the development of abilities and construct strong intellectual skills is education. The perfect manner to shape humans' action and behavior in a desirable way and put together humans in coping with international problems is education (Suwardana,

* PhD scholar, Northern University Nowshehra.

${ }^{* *}$ Associate professor, Northern University Nowshehra.

Email: naeemullah@northern.edu.pk

${ }^{* * *}$ Assistant professor, Northern University Nowshehra.

$=$ International Research Journal of Education and Innovation $=[54]=$ 
2017). The first stage in formal training is Elementary schooling, almost globally furnished free and is compulsory. In Pakistan its duration is of 5 years, from grades 1 to 5 and is followed by 3 years of middle school from grades 6 to eight, and starting at the age of five years. The Elementary education plays a principal function in making human beings, polished, cultured and civilized. All rules of socioeconomic, political, moral, ethical, and social and language requirements of the society are set by the quality of education. The concept, questioning, awareness, distinctive feature, custom, tradition, ability, and the status of a nation go cross around the educational system started in elementary school. The development process in a human society can be accelerated only through a good system of elementary education (Ahmad, et al, 2013).

\section{Elementary Education}

Elementary education provide a foundation for secondary and tertiary education. Elementary education programs should be planned in such a manner to be beneficent for students in their future. Simultaneously these programs should be framed in a novel and appealing style to motivate students (Lindsay, 2007).

It is an admitted fact that first five years of child's life plays an important role in child future achievements. Research proved on the crucial factors in brilliant ECE programs that result in great advantages for young children's success in college and beyond. And despite expanded popularity of the significance of early youth education, the emerging research on the structures needed to scale up ECE programs and align them with K-3 structures to be implemented in any predominant manner (Hillm, et al 2015).

\section{Literature Review}

Visual discrimination ability is imperative in getting a comprehension of the alphabetic perception that is characterized as "the information that language is comprised of discrete sounds. It is a accepted as a set principle that "visual word recognition proceeds via a "visual word form" resemblance. Most of the modern researches on this visual word formation started with alphabetic recognition, then comes word formation, followed by the stages to understand printed sentences to derive meaning out of it and to make it apart of long term memory. The role of physical, mental, and neural perceptions is most vital in understanding the concept of visual discrimination ability followed by first stage of reading i.e. letter recognition (Finkbeiner \& Coltheart, 2009).

Academic performance of students is supported through numerous components. These are present in their preschool life. These incorporate language, intellectual, and social abilities, and socio-economic status and gender (Blair, 2002).

Visual discrimination ability, Letter knowledge, in preschool through elementary school may be a base for future educational accomplishment. Letters knowledge comprise of letter names (LN) and letter sounds (LS) just as realizing the best approach to shape letters. Information on letter-sound establishments or the possibility to fit a letter with the sound it makes is identified with the capacity to sound out and to spell phrases (Huang, et al, 2014).

The visual discrimination isn't just $6 * 6$ vision while sighting something static, dynamic, or

$=$ International Research Journal of Education and Innovation $=[55]=$ 
much more complex, but at the same time it's creative and perceptive. Looking at multiple stimuli which exchange with time and framework assists the students with interpreting the significance and importance of those stimuli. This strategy plays out the capacity of a hyperlink to the brain which interprets this process in a meaningful information (Kurtz, 2006). So visual discrimination and perception is receiving sensory and cognitive data from environment and cognitive segments of visual information are: vision, interest, memory, and recognize originations and distinction of perception challenge apparent (equilibrium of shape, shape, and ground) and area cognition (Garje, et al, 2015).

The visual discrimination ability growth is dependent upon senses where the kid sees the objects, recognize it, and then determines its area in the cognitive operations that's taking information from the environment through the senses and easy and visual discrimination can be defined as incoming Information. Thus, the senses are modes of visual discrimination and sensations are the raw material that makes them to discriminate (Hamid, 2007). A number of techniques and methods had been found relying on the senses to improve visual discrimination ability. Hussein and Bajdaa (2016) reached the conclusion that overcoming learning difficulties at elementary level is through the usage of the curriculum based at the multiplicity of senses or the so - called VAKT style in which hearing, seeing, touching and motion implemented as approach to assist the newcomers recall a way to write words. This technique is based totally on the Vernald method, additionally called the visual, auditory, kinesthetic-tactile (VAKT) which refers to gaining knowledge using senses on the whole in teaching learning process and overcoming the problems faced during the process (Karam \& Kaoud, 2015). Children who have the capability to replicate and hint letters will probably have greater cognitive ability to achieve other abilities, including recoding and reading words (Cameron et al., 2012).

Letter names in English can create confusion for new students. Knowledge of English orthography (the standardized alphabetic spelling device of the English language) problems and their solution can be helpful for teachers, in helping low performing students (McCutchen et al. 2009).

Visual discrimination ability has been proven to correlate with academic performance, especially in elementary school children, (Commodari et al. 2020). One can easily comprehend that proper visual discrimination and analysis ability (i.e., the potential to choose variations in symbols and wreck them down into smaller components) ought to assist a child carry out better academically, because it requires the potential to correctly understand the letter or image. This process help in child's cognition (Kulp, et al. 2004). It has been said that, "The treatment of underlying perceptual deficits enhances the academic process through enhancing visual perception, attention and records processing in those students who manifest problems in those attributes" to enhance visual discrimination ability during early childhood education may prove beneficial for later academic achievements (Scheiman \& Rouse 2006).

Kulp et al (2002), determined that bad visible discrimination ability has a strong association with poor academic performance, poor reading ability, facing problems in math, and other subjects (Stanford Achievement Test) while controlling for age and verbal ability.

Visual discrimination ability may be a reason to the improvement of many essential features

$=$ International Research Journal of Education and Innovation $=[56]=$ 
including cognitive and motor functions and positions of objects in space (Brown et al 2010). Elbasan et al (2011), we may have a connection with our environment through Visual discrimination ability. Its development is furnished by means of a mixture of notion of visuals stimuli, the head and eyes connection, and dominant visible clues, beginning from birth. This ability is extended through experience and vigilance over time, with the stimuli coming from the surroundings. Visual discrimination ability play a vital function in our routine life.

\section{Statement of the Problem}

The problem of the study is to measure the visual discrimination ability among government elementary school children of different age group $4-8$ years in, District Swabi, Khyber Pukhtoonkhwa (Pakistan).

\section{Objectives of the study}

- $\quad$ To measure visual discrimination ability among elementary school children aged 4-8 years,

- To compare visual discrimination ability of rural and urban government elementary school children age 4-8,

- To compare visual discrimination ability of male and female Government elementary school children age 4-8 years.

\section{Method and Procedure}

This study was designed to measure visual discrimination ability of government elementary school children of age 4-8 years. To achieve the objectives of the study, the following research methods were used.

\section{Population}

The population of the study comprised of all the students studying in government, a total of 2.46 million male and 1.91 million female students were enrolled from grade 1-5 in all government schools in Khyber Pukhtoonkhwa. Source: Govt. of Khyber Pukhtoonkhwa (2018).

\section{Sample}

The sample of the study was selected from two government rural schools GGPS Shahmansoor GPS Shahmansoor, and two government urban schools, GGPS Zaida I and II, using the convenient sampling method a total of 320 students were selected. From each school 80 students were selected aged 4-8 years, 20 students were of age 4-5 years, 20 students were of age 5-6years, 20 students were of age 6-7 years, and 20 of age 7-8 years, were randomly selected whose parents $\backslash$ guardian filled the questionnaire with prior approval of school administration. In the government urban and rural schools 20 girls and 20 boys were selected from each age group in every school. In this way a total of 320 students were observed for their visual discrimination ability according to their age group, gender, and living area i.e rural and urban. 


\section{Research Design}

An empirical research design was used to conduct study to investigate the visual discrimination ability of elementary school children.

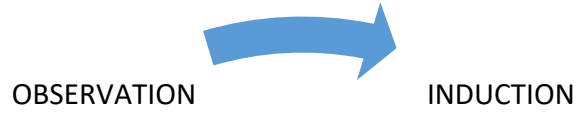

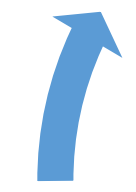

EVALUATION

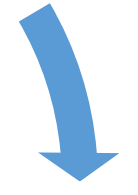

DEDUCTION

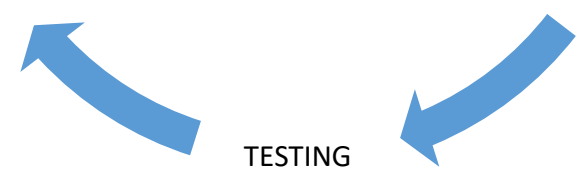

(Ahmad, 2016)

\section{Research Instrument}

Twenty five worksheets for upper case letters, 25 worksheets for lower case letters, and 25 worksheets for 3 letter words were used as research instrument. Letter page sized 8.5" *11" with printing words and letters in Calibri bold 72 sized fonts each with two columns in the 1 st column was printed the alphabet \word to be matched and in $2^{\text {nd }}$ column were given 3 choices matching to the sample. The correct option was randomized for each matching letter $\backslash$ word.

\section{Procedure of the Study}

The sample children of age 4-5 were given 25 worksheets of three matching to sample of uppercase letters. The subject children of age 5-6 were given 25 worksheets of 3 choices matching to sample of uppercase letters. The subject children of age 6-7 were given 25 worksheets of 3 choices matching to sample of lowercase letters. The subject children of age 7-8 were given 25 worksheets of 3 letter words.

Students in each school and each age group were given the relevant worksheet, with prior instructions in national language, in case students were not able to pick the instructions they were instructed in regional language, Pashto. After giving clear instructions children were given 30 minutes to match letter \words with the sample with the specific word.

$=$ International Research Journal of Education and Innovation $=[58]=$ 


\section{Scoring of Responses}

Each child's correct matching response was given ' 1 ' mark out of total 25 marks and '0' mark for each incorrect response.

Following observation sheet was used for scoring the data.

\begin{tabular}{lllll}
\hline S.No. Name & Age in months & $\begin{array}{l}\text { Correct } \\
\text { response }\end{array}$ & $\begin{array}{l}\text { Wrong } \\
\text { response }\end{array}$ & Score \\
\hline
\end{tabular}

Twenty five worksheets for upper case letters, 25 worksheets for lower case letters, and 25 worksheets for 3 letter words were used as research instrument.

\section{Data Collection}

Data was collected through worksheets of upper \& lower case letters, observation sheets and proformas to check students' age and visual discrimination relevancy.

\section{Data Analysis}

Data were analyzed through Statistical package for Social Sciences (SPSS) by applying statistical formulas of mean, median, percentage, and t-test. For individual frequencies of school wise (four age groups i.e. 4-5 years, 5-6 years, 6-7 years, and 7-8 years) data were analyzed by applying mean, percentage, and t-test.

Table 1. Mean, percentage, median and SD of age groups 4-8 years of Urban Government primary schools

\begin{tabular}{llllll}
\hline Age group & $\mathbf{N}$ & Mean & \%age & Median & SD \\
\hline 4-5 year & 40 & 11.13 & 27.8 & 12.0 & 5.08 \\
5-6 year & 40 & 17.58 & 44.0 & 19.0 & 4.24 \\
6-7 year & 40 & 18.30 & 45.8 & 19.5 & 4.23 \\
7-8 year & 40 & 22.95 & 57.4 & 24.0 & 2.83 \\
\hline
\end{tabular}

Table 1 shows that there was increasing trend of visual discrimination ability among children with the increase in the age group of children of government elementary schools in urban areas. Maximum mean (22.95) in the age group of 7-8 years in the urban government schools whereas minimum mean value (11.13) was showed against the age group of 4-5 years in the urban government schools.

Table 2. Mean, percentage, median and SD of age groups 4-8 years of Rural Government primary schools

\begin{tabular}{llllll}
\hline Age group & $\mathbf{N}$ & Mean & \%age & Median & SD \\
\hline 4-5 year & 40 & 12.80 & 32.0 & 13.0 & 3.22 \\
5-6 year & 40 & 17.80 & 44.5 & 19.0 & 3.92 \\
6-7 year & 40 & 17.82 & 44.6 & 19.5 & 4.03 \\
\hline
\end{tabular}

= International Research Journal of Education and Innovation 


\begin{tabular}{llllcc}
\hline \hline $7-8$ year & 40 & 22.95 & 57.4 & 24.0 & 2.68 \\
\hline
\end{tabular}

Table 2 indicates that there was increasing trend of visual discrimination ability among children with the increase in the age group of children of government elementary schools in the rural areas. Maximum mean (22.95) in the age group of 7-8 years in the rural government schools whereas minimum mean value (12.80) was showed against the age group of 4-5 years in the rural government schools.

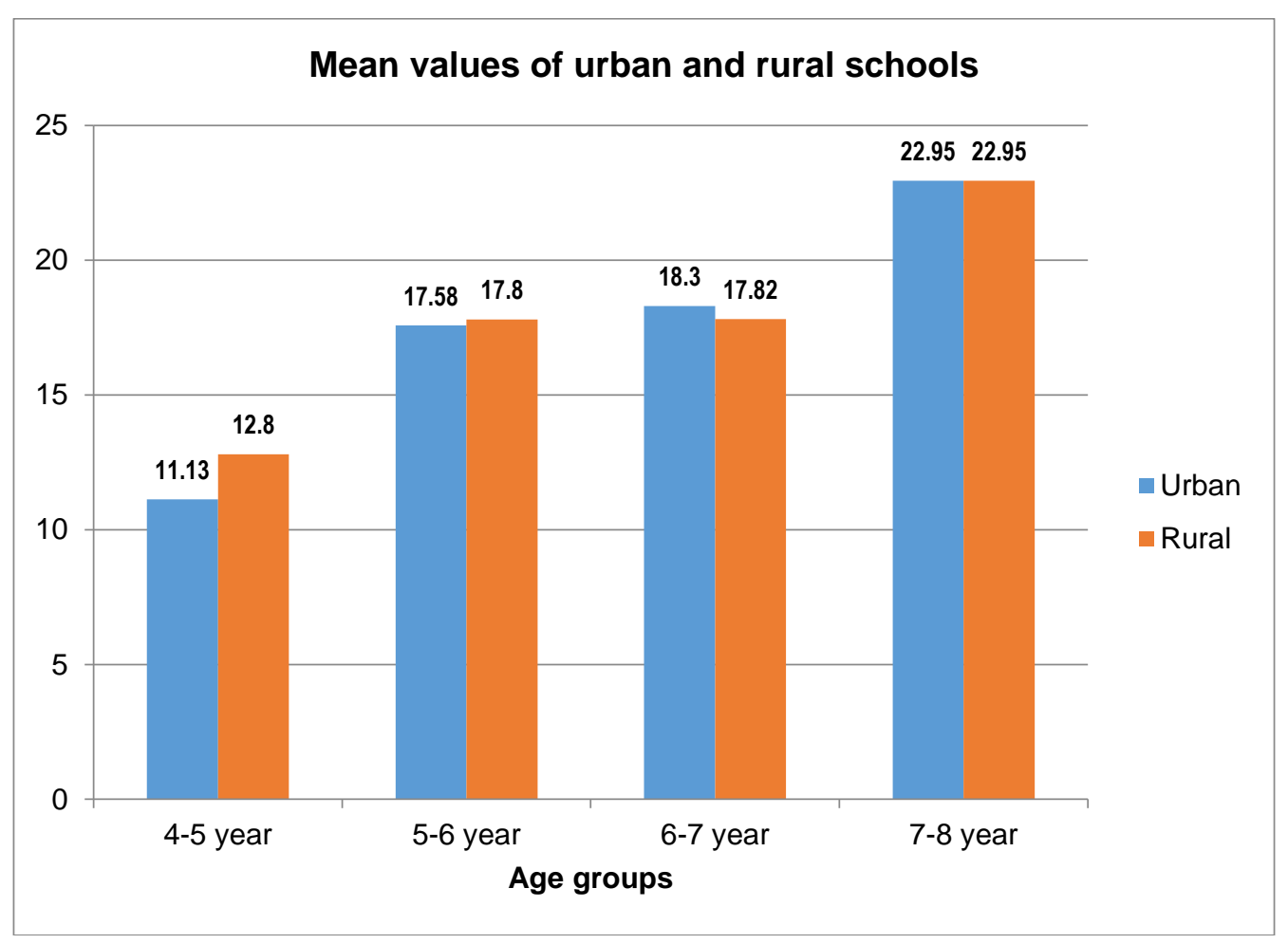

Table 3. t-test and significance of difference in mean values of age 4 to 8 years belong to urban and rural government schools

\begin{tabular}{|c|c|c|c|c|c|}
\hline Group & $\mathbf{N}$ & Age & Mean & df & t-value \\
\hline $\begin{array}{l}\text { Urban government } \\
\text { Rural government }\end{array}$ & 80 & $4-5$ years & $\begin{array}{l}11.13 \\
12.80\end{array}$ & 78 & $1.759 *$ \\
\hline $\begin{array}{l}\text { Urban government } \\
\text { Rural government }\end{array}$ & 80 & $5-6$ years & $\begin{array}{l}17.58 \\
17.80\end{array}$ & 78 & $0.246^{*}$ \\
\hline $\begin{array}{l}\text { Urban government } \\
\text { Rural government }\end{array}$ & 80 & 6-7 years & $\begin{array}{l}18.30 \\
17.83\end{array}$ & 78 & $0.514^{*}$ \\
\hline $\begin{array}{l}\text { Urban government } \\
\text { Rural government }\end{array}$ & 80 & $7-8$ years & $\begin{array}{l}22.95 \\
22.95\end{array}$ & 78 & $0.0^{*}$ \\
\hline
\end{tabular}

*Non-significant

Table value $=2.00$

$=$ International Research Journal of Education and Innovation $=[60]=$ 
Table 3 depicts that $t$-values $(1.759,0.246,0.514$, and 0.0$)$ of urban and rural government elementary schools (age 4-5 years, 5-6 years, 6-7 years, and 7-8 years) were non-significant at 0.05 level. Thus, null hypothesis was accepted. It means that there was no significant difference in the mean values and frequency of urban and rural government elementary schools.

Table 4. T-test and significance of difference in mean values of age 4 to 8 years belong to urban boys and girls

\begin{tabular}{|c|c|c|c|c|c|}
\hline Group & $\mathbf{N}$ & Age & Mean & df & t-value \\
\hline $\begin{array}{l}\text { Urban boys } \\
\text { Urban girls }\end{array}$ & 80 & $4-5$ years & $\begin{array}{l}12.30 \\
12.78\end{array}$ & 78 & $0.446^{*}$ \\
\hline $\begin{array}{l}\text { Urban boys } \\
\text { Urban girls }\end{array}$ & 80 & 5-6 years & $\begin{array}{l}17.98 \\
17.38\end{array}$ & 78 & $0.631^{*}$ \\
\hline $\begin{array}{l}\text { Urban boys } \\
\text { Urban girls }\end{array}$ & 80 & 6-7 years & $\begin{array}{l}20.03 \\
21.13\end{array}$ & 78 & $1.204^{*}$ \\
\hline $\begin{array}{l}\text { Urban boys } \\
\text { Urban girls }\end{array}$ & 80 & $7-8$ years & $\begin{array}{l}22.88 \\
23.65\end{array}$ & 78 & $1.140^{*}$ \\
\hline
\end{tabular}

Table 4 shows that t-values $(0.446,0.631,1.204$, and 1.140) of urban boys and girls of elementary schools (age group of 4-5 years, 5-6 years, 6-7, and 7-8 years) was non-significant at 0.05 level. Thus, null hypothesis was accepted. It means that there was no significant difference in the mean values and frequency of urban boys and girls of elementary schools.

Table 5. T-test and significance of difference in mean values of age 4 to 8 years belong to rural boys and girls

\begin{tabular}{|c|c|c|c|c|c|}
\hline Group & $\mathbf{N}$ & Age & Mean & df & t-value \\
\hline $\begin{array}{l}\text { Rural boys } \\
\text { Rural girls }\end{array}$ & 80 & 4-5 years & $\begin{array}{l}10.25 \\
11.85\end{array}$ & 78 & $2.006^{* *}$ \\
\hline $\begin{array}{l}\text { Rural boys } \\
\text { Rural girls }\end{array}$ & 80 & $5-6$ years & $\begin{array}{l}13.93 \\
14.80\end{array}$ & 78 & $0.894^{*}$ \\
\hline $\begin{array}{l}\text { Rural boys } \\
\text { Rural girls }\end{array}$ & 80 & $6-7$ years & $\begin{array}{l}19.45 \\
18.45\end{array}$ & 78 & $1.274^{*}$ \\
\hline $\begin{array}{l}\text { Rural boys } \\
\text { Rural girls }\end{array}$ & 80 & $7-8$ years & $\begin{array}{l}22.38 \\
23.28\end{array}$ & 78 & $1.011^{*}$ \\
\hline
\end{tabular}

Table 5 shows that $t$ value (2.006) of rural boys and girls of elementary schools (age 4-5 years old) was significant at 0.05 level. Therefore, the null hypothesis was rejected. It means that there was significant difference in the frequency numbers of rural boys and girls of elementary schools. However, $t$-values $(0.894,1.274,1.011)$ of rural boys and girls of elementary schools (age 5-6 years, 6-7 years and 7-8 years) was non-significant at 0.05 level. Thus, null hypothesis was accepted. It means that there was no significant difference in the mean values and frequency of rural boys and girls of elementary schools.

$=$ International Research Journal of Education and Innovation $=[61]=$ 
Table 6. T-test and significance of difference in mean values of age 4 to 8 years belong to government boys and girls

\begin{tabular}{lcllll}
\hline Group & N & Age & Mean & df & t-value \\
\hline Government boys & \multirow{2}{*}{80} & 4-5 years & 10.68 & 78 & $1.097^{*}$ \\
Government girls & & & 11.58 & & \\
Government boys & 80 & 5-6 years & 16.23 & 78 & $0.195^{*}$ \\
Government girls & & & 16.43 & & \\
Government boys & 80 & 6-7 years & 18.25 & 78 & $0.107^{*}$ \\
Government girls & & & 22.70 & 78 & $0.815^{*}$ \\
Government boys & 80 & 7-8 years & 23.20 & 78 \\
Government girls & & &
\end{tabular}

*Non-significant

Table value $=2.00$

Table 6 shows that t-values $(1.097,0.195,0.107,0.815)$ of government boys and girls of elementary schools (age 4-5 years, 5-6 years, 6-7 years and 7-8 years) was non-significant at 0.05 level. Thus, null hypothesis was accepted. It means that there was no significant difference in the mean values and frequency of government boys and girls of elementary schools.

\section{Discussion}

The present research was conducted to investigate into visual discrimination ability of elementary school children aged 4-8 years. The results shows a gradual increase in visual discrimination ability with age. These results were in conformity with Gibson et al. (1962), where a maximum mistakes were seen in age group 4-5 and mistakes came to lowest range by 8 years. Lahey \& Mcnee (1975) also favored that the results of present study. The study found that visual discrimination errors were more in preschool children but show a significant decrease in grade one to three. Barsingerhorn et al. (2018), Bobele (1975), and Wu et al. (2015), all these studies also concluded the same results.

Paradis (1974) concluded that socioeconomic conditions have no effect on the degree of success in letter stimuli test. However Pienaar et al. (2013) and Clarke (2015), pointed out in cross-social studies that a number of social factors as low economic conditions, living in high risk areas, exposure to environmental pollution, inadequate teaching methods can negatively affect children's visual discrimination ability.

The present study also concluded that in comparing locality (urban, rural), and gender (male, female) there was no significant difference in age group 7-8 years. So the children were able to discriminate visually in this age. The same results were shown by Gibson et al. (1962), where he declared that visual discrimination mistakes came to nearly zero by 8 year's age.

\section{Conclusions}

As the age group increased the visual discrimination ability also increased among all the elementary school children. The visual discrimination ability is significant.

The overall mean and percentage values depicted that visual discrimination ability was comparatively lesser than the subsequent age groups. It was the highest in age group of 7-8 years children.

As the age group increased visual discrimination ability increased from lowest level to

$=$ International Research Journal of Education and Innovation $=[62]=$ 
highest level.

It was observed that there was significant difference while comparing visual discrimination ability of 4-5, 5-6, and 6-7 years children but no significant difference was seen in 7-8 years children.

Under the comparison of Male and Female Schools, the visual discrimination ability of age group 4-5 years is better in female children in rural schools than the male children. But the visual discrimination ability in age group 5-6, 6-7 and 7-8 years is not significant in female children and male children.

It was concluded that age was the only factor making significant difference in visual discrimination ability of children aged 4-8 years while no significant difference was seen while comparing gender ( male, female) and locality ( urban, rural ) in government elementary school children.

\section{Recommendations}

- This research study was conducted to investigate the visual discrimination ability of government elementary school children of aged $4-8$ years. The study showed that as the age group increased the visual discrimination ability also increase from lowest to highest level.

- It is therefore recommended that other methods should be used to increase visual discrimination ability. One of these methods is "Letter Reversal Activities", when students are first learning how to read, it's common for them to reverse or confuse letters such as $b, d, p, q, g, m, w, n, s$, and $z$. However, students who continually mix these letters up may need more support. Explicitly teaching strategies for these common reversals can be helpful for students so that when they get stuck, they have a memorable tool to rely on.

- Visual discrimination ability can also be increased with the help of "A-MAZE-ing squares, to provide students with practice in letter discrimination, directionality, focus, and fine motor control.

- Students need extra practice to build visual discriminate skills. Fortunately, these activities can be a fun sorting and matching games provide hands on ways to practice these skills.

\section{References}

1. Ahmad, A. (2016). An Investigation into Number Conservation Ability among Primary School Children of Pakistan According to Piaget's Theory of Cognitive Development. Unpublished, Northern University, Nowshera, Faculty of Arts and Social Sciences, Nowshera.

2. Ahmad, I., Rauf, M., Rashid, A., \& Salam, M. (2013). Analysis of the problems of primary education in Pakistan. Academic Research International, 4(2), 324-330.

3. Barseghian, T. (2011, Febraury 4). Three trends that will shape the future of curriculum. Retrieved from http://blogs.kqed.org/mindshift/2011/02/three-trends-that will-shapethe future-of-curriculum/

4. Barsingerhorn, A.D., Boonstra, F. N., \& Goosens, J. (2018). Development of Symbol discrimination speed in childref with normal vision. Visual Psychophysics and Physiological Optics, 59(10), 3973-3983.

$=$ International Research Journal of Education and Innovation $=[63]=$ 
5. Blair, C. (2002). School Readiness: Integrating cognition and emotion. American Psychologist, 57(2), 111-127.

6. Bobele, R. (1975). Children's Norms for the Visual Retention Test Multiplr choice form 1. Doctoral Dissertation, University of Houston. Houston, Texas, U.S.A.

7. Brown T, Bourne R, Sutton E. (2010). The reliability of three visual perception tests used to assess adults. Percept Mot Skills, 111, 45-59.

8. Cameron, C., Brock, L. L., Murrah, W. M., Bell, L., Worzalla, S., Grissmer, D., \& Morrison, F. J. (2012). Fine motor skills and executive function both contribute to kindergarten achievement. Child Development, 83, 1229-1244.

9. Clarke, K. (2015). Construct Validity of the Development Test of Visual-Perception In Western Australian Primary School. Master Dissertation. Australia. Retrieved from https://ro.ecu.edu.au/theses_hons/20141474

10. Commodari, E., Guarnera, M., DiStefano, A.,\& DiNuovo, S.,. (2020). Childrenlearn to read: How visual analysis and mental imagery contribute to reading performance at different stages od reading aquisition. Journal of Psycholinguistic Research, 49(1), 59-72.

11. Elsban, B., Songul, A., \& Duger, T.,. (2011). Effects of visual perception and motor function on the activities of daily living in children with disabilities. Fizyoterapi Rehabiltasyon, 22(3), 224-230.

12. Finkbeiner, M., \& Coltheart, M. (2009). Letter recognition: From perception to representation. Cognitive Neuropsychology, 26(1), 1-6.

13. Garje, M. V. (2015). Study of the visual and perceptual problems in children with learning disability. Indian Journal of Basic and Applied Medical Research, 4(3), 492-497.

14. Gay, L. R. (2009). Educational Research: Competencies for Analysis and Applications (9th ed.). New Delhi, India: Student Book Company.

15. Gibson. (1969). E Principles of Perceptual Learning and Development. New York: Appleton-Century-Crofts.

16. Gibson, E.J., Gibson, J.J., Pick, A. D., \& Osser, H. (1962). Adevelopmental study of discrimination of letter like forms. Journal of Comparative and Physiological Psycholog, 55(6), 897-906.

17. Goldstand, S. (2005). "Vision, visual-information processing, and academic performance among seventh-grade schoolchildren: a more significant relationship than we thought?". Am J Occup Ther, 59(4), 377-389.

18. Hamid, H. (2007). the impact of self-expression and visual experience in the development of children. Conquest Magzine, 31, 192-212.

19. Huang, F.L. , Tortorelli, L.S. , \& Invernizzi, M.A. (2014). An investigation of factors associated with letter- sound knowledge at kindergarten entry. Early Childhood Research Quarterly, 29(2), 182-192.

20. Hussein, A., \& Bajdaa, A. (2016). Effectiveness of tutorial basedon multisensory strategy for the treatment of some dictation difficultiesfor school girls. Global Institute for Study and Research Journal, 6, 1-32.

21. Karam, L., \& Kaoud, A. (2015). The effectiveness of using method Vernald (Method of multiple senses) in reducing the problem of reading (dyslexia) in a sample of primary school children. Childhood Studies, 67(18), 41-45.

22. Kulp M., Edwards, k \& Endrson. (2002). Is Visual memory predictive of below everage

$=$ International Research Journal of Education and Innovation $=[64]=$ 
academic achievement in second through fourth graders. Optom Vis Sci, 79(7), 431-434.

23. Kulp, M., Mari, J., \& Early. (2004). are visual perceptual skillsrelated to mathematics abilityin second through sixth grade children. Focus on Learning Problems in Mathematics, 26(4), 44-48.

24. Kurtz, L. (2006). Problems with perceptionin the visual children with the ADHD and other learning disabilities. London: Jessica Kingsely Publishers.

25. Lahey, B.B., \& McNees, M. P. (1975). Letter discrimination errors in kindergarten through third grade: Assessment and operant training. Journal of Special Education, 9, 191-199.

26. Lindsay, G. (2007, March). Educational psychology and the effectiveness of inclusive education/mainstreaming. British Journal of Educational Psychology, 77(1), 1-24.

27. Mandinach, E., \& Gummer, E. (2013). A systemic view of implenenting data literacy in educator preparation. Educational Researcher, 42, 30-37.

28. McCutchen, D., Green, R., \& Sanders, E. (2009). Further evidence for teacher knowledge. Reading and Writing, 22(4), 401-423.

29. Paradis, E. E. (1974). The appropriateness of visual discrimination exercises in reading readiness material. The Journal of Educational Research, 67(6), 276-278. doi:10.1080/00220671.1974.10884627

30. Pienaar, A.E., Barhorst, R., \& Twisk, J.W.R. (2013). Relationships between academic performance, SES school type and perceptual-motor skills in first grade South African learners: NW-CHILD study. Child: Care, Health and Development, 40(3), 370-378. doi:10.111/cch.12059

31. Scheiman, M. \& Rouse, W. (2006). Optometric management of learning-related vision problems. Missouri, USA: Mosby-Elsvier.

32. Straub, E. (2009). Understanding technology adoption: Theory and future directions for informal learning. Review of Educational Research, 79, 625-649.

33. Suwardana, H. (2017). Revolusi industri berbasis revolusi mental (Industrial RevolutionBased on Mental Revolution). JATI UNIK, 1(2), 102-110.

34. Teufel, C., \&Nanay, B. (2017). How to (and how not to)think about top down influence on visual perception. Consciousness and Cognition, 47, 17-25.

35. Venter, L., Richmond, J., \& Taylor, M. (2018). South African Journal of Occupational Therapy, 24-30.

36. Venter, Lucinda, J, R., \& Taylor, M. (2018). Convergentvalidity of the Richmond Reversal Rating in relation to visual spatial perception as measured bySASP. South African Journal of Occupational Therapy, 48(3), 24-30. doi:http://dx.doi.org/10.17159/23103833/2017/vol48n3a5

37. Wu, H. M., Chin, K.L., Yang, YM., \& Kuo, B. (2015). The development and discussion of computrizwd visual perception assessment tool for Chinese character structuresConcurrenr estimation of the overall ability and the domain ability in item responsebtheory approach. Research in Developmental Disabilities, 36, 447-458.

$=$ International Research Journal of Education and Innovation $=[65]=$ 